\title{
Perception of Beneficiaries and Stakeholders About Vocational Education in Ghana: A Case Study in Ashanti Region, Ghana
}

\author{
Jemima Evelyn Andoh-Nartey Elizabeth Kafui Senya (Mrs.) \\ Lecturer at Department of Hotel Catering and Institutional Management, School of Applied Science and Arts; \\ Accra Technical University, Ghana
}

\begin{abstract}
Background: Technical and Vocational Education is considered by many nations as an important catalyst in the development of a country, however much investment and research have not been done to enriching vocational education. This study therefore, delve into the perception and factors that influence beneficiaries in acquiring vocational education, and the impact of vocational education on vocational graduates and also to assess the factors the inhibit the full actualization of skills acquired from vocational education.

Methods: In pursuit of the stated objective descriptive cross-sectional survey was adopted as the research design for this study. Data was sourced from both primary and secondary sources. Structured questionnaire which was the main research instrument was used to elicit information from the participants consisting beneficiaries and stakeholders from Kumasi Metropolitan Assembly in the Ashanti Region of Ghana.

Results: The findings showed an $\mathrm{R}^{2}$ value of 0.874 which reveals that, the factors influence the choice of vocational education by beneficiaries accounted for $0.0874 \%$ of the variation in a choice vocational education. The f-statistics of 86.922 reveals that the model is statistically significant at 0.05 significant level. On the impact of vocational education on the beneficiaries' occupation, majority of them agreed to the fact that vocational education gave them the necessary technical and entrepreneurial skills. The beneficiaries however have a negative perception about vocation education while stakeholders hold a contrary perception.

Conclusion: Vocational education plays a critical role in development hence governments must prioritise vocational education development. However, developing vocational education requires a complete understanding of the factors that affect vocational education development; hence a broader study should be conducted to identify these factors.
\end{abstract}

DOI: $10.7176 / \mathrm{JEP} / 11-5-01$

Publication date: February $29^{\text {th }} 2020$

\subsection{INTRODUCTION}

Vocational skills acquisition seems to appear as a remedy to the sudden reality of unemployment among graduates of tertiary institution. Vocational skill is the acquisition of technical and handy skills and knowledge from vocational careers such as catering, basketry, carpentry, tailoring, plumbing, fashion designing, masonry, computing, engineering etc. It has come to the realization that vocational skills acquisition has become a means of livelihood and a decent way of earning a living among vocational graduate. Ugwuja (2010) speculated that vocational skills acquisition which is the acquisition of specific skills for self - employment or career has become a major part of the average student education plan." It is a fact that no country can develop without quality technical and vocational education and training (TVET) sector. Three different forms of technical and vocational education training have evolved in Ghana over years namely formal system, informal system and non - formal system. It is offered by institutions such as the National Vocational Training Institute (NVTI), Ghana Education Service (GES) technical institute, private vocational and technical institutions. Non - formal (TVET) consist of workshops, short courses and seminars and has typically structured learning objectives, learning times and supports which does not lead to certification. The informal sector typically includes traditional apprenticeships which have a wide range of flexible programs and processes by which an individual acquires knowledge and skills from designated training venues (Sherry et al 2013).

Again, Mustapha \& Greeman (2002) also stressed that the economic competitiveness of a country depends on the skills of its workforce. The skills and the competencies of the workforce, in turn, are dependent upon the quality of the country's education and training system, hence the need to develop vocational and technical education system to develop the skill of the labour force. Herkert (2002) also stated that, education must also seek to develop the processes of intelligence so that the individual is capable of going beyond the cultural ways of his social world, able to innovate in however modest way so that he can create an interior culture of his own. Vocational Education therefore, has an imperative role to play in raising the quality of work and quality of vocational graduates, increasing job satisfaction and motivating workers as well as enhancing productivity (Manifred \& Jennifer, 2004). In the new economic environment of Ghana therefore, Vocational Education is expected to produce an educated, skilled and motivated work force.

The UN Millennium Development goals also support Vocational Education and it has been established that productive unemployment and self-employment are the best weapons for fighting poverty. Vocational education 
taps the resources of people and enterprises to contribute to economic vitality. Vocational education helps people develop capacities and competence which are necessary for the implementation of policies in sections such as health, energy, environment and rural development and for ensuring their broad-based impact in society (Seyfried, 1998).

Over the years, numerous people have acquired vocational and technical education but the rate of unemployment still increase unabated in Ghana. Again, a cursory observation by the researcher revealed that most beneficiaries (those who have acquired vocational education) and stakeholders in vocational programmmes have a feeling of inferiority in comparison with their counterparts in academic programmes. In addition, vocational education in Ghana is laced with numerous challenges that makes the public question the contribution of vocational education to economic development. The key question is that, does vocational education equip vocational graduates with the requisite skills for the job market or it is deficient in its services? The main thrust of this study was to delve into the perception of beneficiaries and stakeholders on the impact of vocational education on vocational graduates and also to assess the factors the inhibit the full actualization of skills acquired from vocational education.

\subsection{Objectives of the Study}

The general objective of the study is to be acquainted with and reveal beneficiaries and stakeholders' perceptions towards vocational education. In other words, to acquire knowledge and explore what beneficiaries and stakeholders in Ashanti Region have towards vocational education. In pursuit of the main objective, threepronged specific objectives have been outlined to guide the study. These are;

- To identify factors that influences choices of vocational education

- To examine the impacts of vocational education on beneficiaries work for living

- To explore the factors that inhibit beneficiaries from actualizing practical skills acquired through vocational education.

\subsection{Significance of the Study}

The study is significant because it would provide information about how people who have benefited and those who are stakeholders of Vocational Education perceive the programme and device means to improving it. It would also help teachers to select the best method to teach students of vocational education. More importantly the research report will serve as a reference as well as provide an insight into further studies in the perception of beneficiaries and stakeholders on vocational education.

\subsection{LITERATURE REVIEW}

\subsection{The New Paradigm in Vocational Education}

Shantaram (2012) explains vocational education as all forms and levels of the educational process, including general knowledge and academic skills; it entails the study of technologies and related sciences, the acquisition of practical skills, know-how, attitudes and understanding relating to occupations in the various sectors of economic and social life. According to Murray (2004), the main purpose of vocational education in the $20^{\text {th }}$ century was to prepare students for work in an industrialized economy. However, the advent of the $21^{\text {st }}$ century has changed the concept of vocational education to a more wholistic approach to prepare students for the world of work. Unlike the former which prepared students for entry level jobs that required less than four-year college degree. Murray (2004) therefore encourage vocational students to continue their studies to the doctorial degree level.

\subsection{Factors That Influence Choices of Vocational Education}

Randal (2012) posited that there are several factors that affect students' choice of vocational education and these factors can be classified into academic and non-academic factors. These factors encompass socio-economic status of parents, personal interest, availability of employment after programmes etc.

- Socio-Economic Status of Parents and their involvement in the Learning Process of their Children: the social status of student's parents is a key determinant of their choice of vocational education. For instance, parents of high social class oftentimes want their children to offer secondary related courses instead of vocational or technical courses and vice versa. These set of parents have the perception that vocational education is for low class people who cannot afford the cost of secondary education. According to Finn (1972), the nature of parents' involvement whether economically or socially is influenced by the nature of interactions a child has with his/her parents at home. Again, when parents get involved in affairs of their children, academic performance improves. Parental influence is more profound than that of school.

- Personal Interest of the Student: here, the choice of vocational education is largely influenced by the student's interest. The personal interest of students can be explained using two main theories - 
Holland's Trait-factor theory and Developmental theories by Eli Ginzberg \& Donald. A trait-factor theorist of note, Holland (1971), has provided a highly rational explanation of the relationship between personality traits and career development. Unlike most other theorists who emphasize the matching of individuals $^{\text {ee }}$ abilities to particular jobs, his theory model centred on how individuals with given personality characteristics are likely to react in work environments that are congruent with their characteristics. Holland's major point is that a person's choice of a vocation is an expression of his personality and that interest inventories are expression of personality and their preferred work environments. The developmental theories on the other hand, according to Ekpenyong (2005), have had an overwhelming influence on careers guidance. The basic tenet of developmental theorists is that career aspiration, occupation choice and job entry constitute aspects of individual's developmental tasks. The two key developmental theorists include Eli Ginzberg and Donald Super. For Ginzberg, the central assumption is that occupational choice has an irreversible process and not a once-for-all event. By irreversibility, he meant that the skill and experience acquired in one career affect future decision on career choice. Simply put, a person in a person-oriented job seeking to change jobs would normally tend to go for that which is already acquired skill and experience would be in congruence. Ginzberg sees career development as covering three major stages:

$>$ Fantasy stage: $(0-11$ years $)$

$>$ Tentative stage (early adolescent: 11-17years).

$>$ Realistic stage (adolescent and adulthood: 17years onward).

Career choice, Ginzberg claims, involves making compromise, that is choosing a career which one can make maximum use of one's interests and capabilities in such a manner that will satisfy his goals, but in doing that, "one has to weigh the environmental factors likely to either enhance or inhibit achieving a maximum degree of satisfaction in one's life and work".

\subsection{Factors that Prevent People from Practising Skills Acquired in Vocational Education}

In recent years, vocational education is gaining incredible importance in Ghana, and the government is considering making it free. The lack of employability as an outcome of the education system has given rise to the need for skill-based education. The development and economic growth of Ghana will be accelerated if the youth of our country get vocational education and acquire relevant skills. The State is emphasizing on building skilled human resources for the growth of the individual and the country at large.

However, at present Vocational Education and training system is fragmented, unregulated and lacks quality. Therefore, there is a need to redefine the objectives of Vocational Education so as to align with the changing environment and industrial needs.

\subsection{RESEARCH METHODS \\ 3.1 Research Design}

This study adopted a descriptive survey design in understanding the perception about vocational education, factors that influence the choice of vocational education and the factors that limit the application of skills acquired from vocational education. Fraenkel and Wallen (2000) observed that the purpose of descriptive research is to observe, describe and document aspects of phenomenon as it naturally occurs. The design therefore, involves collecting data through administration of questionnaire to elicit information towards perception of beneficiaries and stakeholders about vocational education in Ghana. Thus, it describes conditions as they exist at the time the research was conducted. Descriptive survey affords the opportunity to select a sample from the population being studied and make generalization from the study of the sample (Best \& Kahn, 1993; Gay, 1992).

\subsection{Population and Sample Size}

According to Polit and Hungler (1997), a research population is an entire aggregation of cases that meet a designated set of criteria. Here, the population entails all stakeholders and beneficiaries of vocational education in Kumasi Metropolitan Assembly in the Ashanti Region. Since the exact population is difficult to defined, a purposive sampling method was used to select a sample of 180 respondents, comprising of 140 beneficiaries (i.e. those who have acquired vocational education) and 40 stakeholders (teachers and governmental departments who manage vocational education).

\subsection{Data Sources and Analysis}

Primary data was obtained from the respondents via questionnaires which was the main research instrument. The questions in the questionnaire were structured in a manner that helped the researchers meet the research objectives. Secondary data which was mainly used for the literature review were gathered from relevant academic journals, books, articles etc.

The data gathered in this research was analysed statistically by the use of a computer programme, Statistical 
Package for Social sciences (SPSS) version 20.0. Being a descriptive survey research, both descriptive and inferential statistics were used to analyse the data. The questionnaires returned by the respondents were serially numbered to facilitate identification. They were then edited, scored, coded and tabulated using a scoring key prepared by me. Results on biographic data of respondents were analysed using descriptive statistics.

\subsection{RESULTS AND DISCUSSION}

\subsection{Introduction}

The results and discussion is subdivided into three main parts. The first part presents results on the respondents' demographic characteristics, the second part presents results gathered from beneficiaries pertaining to the subject, and the final part presents results from relevant stakeholders.

\subsection{Part One}

\subsubsection{Demographic Characteristics of the Respondents}

4.2.2 Normality Test

The analysis of the results pertaining to the respondents' demographic was preceded by a normality test on the respondents' demographic data in order to ascertain its adequacy in making statistical inferences.

According to the central limit theorem, as long as the sample size is 30 or more; the sampling distribution would tend to be normal irrespective of the population distribution. The sample size used in this study was large enough to satisfy the requirement of normality according to the central limit theorem (Field, 2009). Besides the study used 180 respondents from one region which is fairly representative enough to making generalization on the population (i.e. beneficiaries and stakeholders of vocational education). Meyer et al. (2005) also noted that the larger the sample size used in the study, the more precise and stable the estimates of the population parameter would be for statistical inferences.

Kline (2011) emphasized that, skewness level with absolute values greater than 3 are regarded as extreme and a kurtosis level with absolute values greater than 8 are described as extreme. When the acceptable level of skewness (3) and that of kurtosis (8) are violated, it suggests a problem that should be addressed before performing any inferential statistical analysis. The result showed that the maximum value for skewness was 0.294 and the maximum value for kurtosis was -1.07 . Since the skewness values are within the acceptable level (3) and kurtosis values were also within the acceptable level (8), the demographic data appeared to be normal related to each of the indicator variables used in the study. The skewness and kurtosis values of the respondents' demographics are shown in Table 4.1.

\subsubsection{Socio-Demographic Characteristics of Participants.}

The basic rationale for soliciting information on the respondents' demographic characteristics is simply to assess whether or not the respondents are qualified and capable of speaking to the subject. From the results gathered, 34 $(68 \%)$ of the respondents were male whiles the remaining $16(32 \%)$ were female. On age, most of the respondents about 70(38.9\%) were below 25yrs, 36(20\%) were between the ages of 25-34yrs, 40(22.2\%) falls within the ages of 35-44yrs and $30(16 \%)$ are within the age bracket of 45-54yrs. In addition, it was only $4(2.2 \%)$ of the respondents that were above 54yrs. From the results, it evident that majority of the respondents are above $25 y r s$ hence they are of age and well-matured to appreciating the concept of the study. Table 4.1. provides a summary of the respondents' demographics.

Table 4.1: Socio-Demographic Characteristics of Participants

\begin{tabular}{l|l|l|l}
\hline Demographic Characteristics & Frequency (\%) & Skewness & Kurtosis \\
\hline Sex & $77(42.8 \%)$ & $\mathbf{- 0 . 2 9 4}$ & $\mathbf{- 1 . 9 3 5}$ \\
$\quad$ Male & $103(57.2 \%)$ & & \\
$\quad$ Female & & $\mathbf{0 . 4 5}$ & $\mathbf{- 1 . 0 7}$ \\
Age of the Respondents & $70(38.9 \%)$ & & \\
Below 25yrs & $36(20 \%)$ & & \\
$25-34 y r s$ & $40(22.2 \%)$ & & \\
$35-44$ yrs & $30(16.7 \%)$ & & \\
$45-54$ yrs & $4(2.2 \%)$ & & \\
Above 54yrs &
\end{tabular}

Source: Field Data, 2015

\subsection{Part Two}

\subsubsection{Selection and Impact Vocational Education on Beneficiaries.}

This particular part delves into the various factors that went into the selection of vocational education by beneficiaries and also how vocational education has impacted on the work lives of these beneficiaries. However, before these factors are established and highlighted, two key tests are run to determine the consistency in the indicator variables (i.e. statements that represents the various factors that led the beneficiaries in selecting and 
acquiring vocational education) and also to establish the extent by which the indicator variables are representative of the latent variables (i.e. selection of vocational education). These tests are reliability test and convergent validity test.

\subsection{2.: Reliability Test}

The reliability test help determine the consistency in the indicator variables, and this estimated by the Cronbach's alpha. The Cronbach's alpha is adequate if the score is 0.70 or above. The Cronbach's alpha reliability coefficient normally ranges between 0 and 1 . The closer the coefficient is to 1.0 , the greater is the greater is the internal consistency of the items (indicator variables). The reliability test summary is presented below in Table 4.2

Table 4.2: Reliability Test Summary

\begin{tabular}{|c|c|c|c|}
\hline LATENT VARIABLE & & Indicator Variable & $\begin{array}{l}\text { Cronbach's } \\
\text { Alpha }\end{array}$ \\
\hline Selection of Vocational education & 1 & Deliberate selection by oneself & 1.000 \\
\hline & 2 & Selection based on parent's financial status & .847 \\
\hline & 3 & Selection based on its social status & .895 \\
\hline & 4 & Selection based on ease of employment & .946 \\
\hline & 5 & Selection based on ease of passing exams & .894 \\
\hline Impact of Vocational Education on & 6 & It prepares beneficiaries adequately & .972 \\
\hline & 7 & $\begin{array}{l}\text { It prepares beneficiaries well for competitive } \\
\text { market }\end{array}$ & .913 \\
\hline & 8 & It gives beneficiaries the needed technical skills & .984 \\
\hline & 9 & It helps beneficiaries acquire entrepreneurial skills & .978 \\
\hline Perception of & 10 & There is enough training at vocational institution & .981 \\
\hline & 11 & Teachers and instructors were skilful trainers & .982 \\
\hline & 12 & Vocational schools were well equipped & .978 \\
\hline & 13 & $\begin{array}{l}\text { Vocational education was for below average } \\
\text { students }\end{array}$ & .890 \\
\hline & & Overall Scale Reliability & 0.994 \\
\hline
\end{tabular}

\section{Source: Survey result, 2015.}

From table 4.2, all the latent variables and their corresponding indicator variables consisted of multi-item questions. As reported by Glien \& Glien (2003), a single item question or statement is not reliable to draw conclusions as compared to summated multi-item questions. In this study, selection of vocational education, impact of vocational education on beneficiary's occupation and perception regarding training received from vocational institution were the latent variables with their respective indicator variables. From the table above, all the indicator variables were consistent with the latent variables. In addition, the overall scale reliability is 0.994 which generally depicts that the entire data on the latent variables are consistent and reliable.

\subsection{3: Convergent Validity Test}

The convergent validity of the variables was tested by evaluating the extent to which each indicator variable is representative of its respective latent variable. The pattern coefficients that measure the extent to which the indicator variables define their respective latent variables were presented below in Table 4.3. The factor loading was found to be greater than 0.70 which revealed a strong tie between each latent variable and the respective indicator variables. 
Table 4.3: Convergent Validity Test

Cronbach's

\begin{tabular}{|c|c|c|c|}
\hline \multirow{6}{*}{ Selection of Vocational education } & & & Alpha \\
\hline & 1 & Deliberate selection by oneself & .976 \\
\hline & 2 & Selection based on parent's financial status & .920 \\
\hline & 3 & Selection based on its social status & .947 \\
\hline & 4 & Selection based on ease of employment & .976 \\
\hline & 5 & Selection based on ease of passing exams & .960 \\
\hline \multirow[t]{4}{*}{$\begin{array}{l}\text { Impact of Vocational Education } \\
\text { on the beneficiary work life }\end{array}$} & 6 & It prepares beneficiaries adequately & .972 \\
\hline & 7 & It prepares beneficiaries well for competitive market & .966 \\
\hline & 8 & It gives beneficiaries the needed technical skills & .979 \\
\hline & 9 & It helps beneficiaries acquire entrepreneurial skills & .984 \\
\hline \multirow{4}{*}{$\begin{array}{l}\text { Perception of Beneficiaries } \\
\text { regarding training received from } \\
\text { Vocational Institution }\end{array}$} & 10 & There is enough training at vocational institution & .978 \\
\hline & 11 & Teachers and instructors were skilful trainers & .980 \\
\hline & 12 & Vocational schools were well equipped & .971 \\
\hline & 13 & $\begin{array}{l}\text { Vocational education was for below average } \\
\text { students }\end{array}$ & .957 \\
\hline
\end{tabular}

\section{Source: Survey result, 2015.}

\subsection{Descriptive Analysis}

From the descriptive analysis, it emerged that the average mean score of the indicator variables under the various factors that influence the selection of vocational education was $3.014(\mathrm{SD}=1.305)$ and that of the indicator variables which denoted the impact of vocational education on the beneficiaries occupation was $3.165(\mathrm{SD}=$ 1.408), Again, the mean average score of the indicator variables under the perception of beneficiaries regarding training received from vocational institution was $3.19(\mathrm{SD}=1.341)$. These figures are slightly greater than the midpoint of the scale, thus indicating that the respondents generally agreed to the various indicator variables under each latent variable.

In addition, standard multiple regression was used to construct a predictive model for the selection of vocational education by using its indicator variables. The analyses showed that the most dominant factor that influence the selection of vocational schools by the beneficiaries was "the ease of employment after the vocational programme" (VIF = 15.777). Comprehensively, the overall regression analysis unravelled that all the indicator variables under the selection of vocational education have the capacity of influencing the choice of a vocational education. (i.e. $\mathrm{R}=0.874$, $\mathrm{R}$ Squared $=0.764$ ). Furthermore, the coefficients under column $\mathrm{B}$ in table 4.4.2 shows that there is a negative relationship between indicator variable 1 (selection of vocational education by oneself) and 3 (selection of vocational education based on its social status). This can be observed in table 4.4.2 below.

Further analysis was conducted with one-way analysis of variance (ANOVA) to explore the association of the first five indicator variables with the selection of vocational education. The analysis of the participants responses with respect to the indicator variables under the selection of vocational education revealed that the mean value for each indicator variable is above 3 in exception of indicator variable 2, and 5 . And all the indicator variables are significant (i.e. using the F-test). The value 3 was used to denote neutral $4=$ agree and $5=$ strongly agree. Hence the closer the mean value to 5, the higher the level of agreement on that particular indicator variable. Again, the closer the mean value to 1 the more the respondents strongly disagree with the said indicator variable (see table 4.4.3 and table 4.4.2). It is evident that the respondents agreed to indicator variable 1 , and 4, and disagreed with 2, and 5; while the result for indicator variable 3 is predominately neutral. 


\subsubsection{Descriptive Statistics}

\begin{tabular}{|c|c|c|c|c|c|c|}
\hline & $\mathrm{N}$ & Mean & & Variance & \multicolumn{2}{|c|}{ Skewness } \\
\hline & Statistic & Statistic & Statistic & Statistic & Statistic & $\begin{array}{l}\text { Std. } \\
\text { Error }\end{array}$ \\
\hline Selection of Vocational Education by Oneself & 140 & 3.34 & 1.371 & 1.879 & -.423 & .205 \\
\hline $\begin{array}{l}\text { Selection of Vocational Education based on parents' } \\
\text { financial status }\end{array}$ & 140 & 2.44 & 1.364 & 1.860 & .709 & \\
\hline $\begin{array}{l}\text { Selection of vocational education based on its social } \\
\text { status }\end{array}$ & 140 & 3.08 & 1.151 & 1.325 & -.012 & .2 \\
\hline $\begin{array}{l}\text { Selection of vocational education based on easy } \\
\text { employment after the programmed }\end{array}$ & 140 & 3.43 & 1.242 & 1.542 & -.360 & \\
\hline $\begin{array}{l}\text { Selection of vocational education based on the ease of } \\
\text { passing than other courses }\end{array}$ & 140 & 2.78 & 1.399 & 1.958 & .323 & \\
\hline Average & & 3.014 & 1.305 & & & \\
\hline Vocational education prepared beneficiaries adequately & 140 & 3.21 & 1.398 & 1.954 & -.358 & .20 \\
\hline $\begin{array}{l}\text { Vocational education prepared beneficiaries well for } \\
\text { competitive market }\end{array}$ & 140 & 2.86 & 1.447 & 2.095 & .138 & \\
\hline $\begin{array}{l}\text { Vocational education gave beneficiaries the needed } \\
\text { technical skills }\end{array}$ & 140 & 3.31 & 1.410 & 1.987 & -.356 & \\
\hline Vocational education brings about entrepreneurial skills & 140 & 3.28 & 1.378 & 1.900 & -.281 & .20 \\
\hline Average & & 3.165 & 1.408 & & & \\
\hline Enough training from Vocational Education institution & 140 & 3.34 & 1.323 & 1.750 & -.414 & .205 \\
\hline Teachers and instructors were skilful trainers & 140 & 3.35 & 1.404 & 1.970 & -.424 & .20 \\
\hline Vocational schools were well equipped & 140 & 3.41 & 1.341 & 1.797 & -.580 & 205 \\
\hline Vocational education was for below average students & 140 & 2.66 & 1.295 & 1.678 & .387 & .20 \\
\hline Average & & 3.19 & 1.341 & & & \\
\hline Valid N (listwise) & 140 & & & & & \\
\hline
\end{tabular}

Table 4.4.2 Coefficients ${ }^{\mathrm{a}}$

\begin{tabular}{|c|c|c|c|c|c|c|c|c|c|}
\hline \multirow[t]{2}{*}{ Model } & \multicolumn{2}{|c|}{$\begin{array}{l}\text { Unstandardized } \\
\text { Coefficients }\end{array}$} & $\begin{array}{l}\text { Standardized } \\
\text { Coefficients }\end{array}$ & \multirow[t]{2}{*}{$\mathrm{t}$} & \multirow[t]{2}{*}{ Sig. } & \multicolumn{2}{|c|}{$\begin{array}{l}95.0 \% \text { Confidence } \\
\text { Interval for B }\end{array}$} & \multicolumn{2}{|c|}{$\begin{array}{l}\text { Collinearity } \\
\text { Statistics }\end{array}$} \\
\hline & B & $\begin{array}{l}\text { Std. } \\
\text { Error }\end{array}$ & Beta & & & $\begin{array}{l}\text { Lower } \\
\text { Bound }\end{array}$ & $\begin{array}{l}\text { Upper } \\
\text { Bound }\end{array}$ & Tolerance & VIF \\
\hline (Constant) & .773 & .076 & & 10.147 & .000 & .622 & .924 & & \\
\hline $\begin{array}{l}\text { Selection of Vocational } \\
\text { Education by Oneself }\end{array}$ & -.036 & .047 & -.101 & -.764 & .446 & -.129 & .057 & .101 & 9.877 \\
\hline $\begin{array}{l}\text { Selection of Vocational } \\
\text { Education based on } \\
\text { parents financial status }\end{array}$ & .193 & .051 & .537 & 3.783 & .000 & .092 & .294 & .087 & 11.470 \\
\hline $\begin{array}{l}\text { Selection of vocational } \\
\text { education based on its } \\
\text { social status }\end{array}$ & -.209 & .061 & -.490 & -3.424 & .001 & -.329 & -.088 & .086 & 11.660 \\
\hline $\begin{array}{l}\text { Selection of vocational } \\
\text { education based on easy } \\
\text { employment after the } \\
\text { programmed }\end{array}$ & .039 & .066 & .100 & .598 & .551 & -.091 & .169 & .063 & 15.777 \\
\hline $\begin{array}{l}\text { Selection of vocational } \\
\text { education based on the } \\
\text { ease of passing than other } \\
\text { courses }\end{array}$ & .279 & .057 & .798 & 4.859 & .000 & .166 & .393 & .065 & 15.319 \\
\hline
\end{tabular}

a. Dependent Variable: Did you deliberately decided to attend Vocational School 
Table 4.4.3: Model Summary ${ }^{\mathrm{b}}$

\begin{tabular}{|l|r|r|r|r|r|}
\hline Model & R & R Square & Adjusted R Square & $\begin{array}{c}\text { Std. Error of the } \\
\text { Estimate }\end{array}$ & Durbin-Watson \\
\hline 1 & $.874^{\mathrm{a}}$ & .764 & .756 & .242 & .209 \\
\hline
\end{tabular}

a. Predictors: (Constant), Selection of vocational education based on the ease of passing than other courses, Selection of Vocational Education by Oneself, Selection of vocational education based on its social status, Selection of Vocational Education based on parents financial status, Selection of vocational education based on easy employment after the programmed

b. Dependent Variable: Did you deliberately decided to attend Vocational School

Table 4.4.4: ANOVA $^{\mathrm{a}}$

\begin{tabular}{|rl|r|r|r|r|r|}
\hline Model & Sum of Squares & df & Mean Square & F & Sig. \\
\hline \multirow{2}{*}{1} & Regression & 25.523 & 5 & 5.105 & 86.922 & $.000^{\mathrm{b}}$ \\
& Residual & 7.869 & 134 & .059 & & \\
& Total & 33.393 & 139 & & & \\
\hline
\end{tabular}

a. Dependent Variable: Did you deliberately decided to attend Vocational School

b. Predictors: (Constant), Selection of vocational education based on the ease of passing than other courses, Selection of Vocational Education by Oneself, Selection of vocational education based on its social status, Selection of Vocational Education based on parents financial status, Selection of vocational education based on easy employment after the programmed

\subsubsection{Impact of Vocational Education on Beneficiaries Occupation}

Results on the indicator variables under the impact of vocational education on the beneficiaries work life revealed that it prepares the beneficiaries adequately for the job market, gives the beneficiaries the necessary technical skills required for their current occupation and also equipped them with entrepreneurial skills. However, most of the respondents disagreed to the fact that vocational education prepares them well for competitive market. This conclusion was arrived at through the combination of results on 'strongly agree' and 'agree'; and 'strongly disagree' and 'disagree'. This can be observed in table 4.5.

\subsubsection{Factors Inhibiting Beneficiaries to Practice skills acquired from training.}

With government main agenda to promoting vocational education, it is worrisome if skills acquired cannot be translated into practical productive ventures. According to the beneficiaries, the various factors that prevent them to practice skills acquired from vocational training are; the huge amount of money needed before opening a vocational venture, limited training skills acquired from vocational institution and the high interest rate on loans which makes it virtually impossible to access fund to set up a venture. Most of them however disagreed on the fact that competition on vocational ventures was high. This can also be observed on table 4.5

Table 4.5

\begin{tabular}{|c|c|c|c|c|c|c|}
\hline \multicolumn{2}{|r|}{ STATEMENT } & $\begin{array}{c}\text { Strongly } \\
\text { Disagree } \\
\text { (1) } \\
\end{array}$ & Disagree & $\begin{array}{c}\text { Neutral } \\
\text { (3) }\end{array}$ & $\begin{array}{l}\text { Agree } \\
(4)\end{array}$ & $\begin{array}{c}\text { Strongly } \\
\text { Agree } \\
\text { (5) }\end{array}$ \\
\hline \multirow{3}{*}{$\begin{array}{l}1 \\
2\end{array}$} & $\begin{array}{l}\text { Impact of Vocational Education (VE) } \\
\text { on the Beneficiaries work life }\end{array}$ & & & & & \\
\hline & It prepares beneficiaries adequately & $24(17.1 \%)$ & $23(16.4 \%)$ & $12(8.6 \%)$ & $52(37.1 \%)$ & $29(20.7 \%)$ \\
\hline & $\begin{array}{l}\text { It prepares beneficiaries well for } \\
\text { competitive market }\end{array}$ & $33(23.6 \%)$ & $33(23.6 \%)$ & $20(14.3 \%)$ & $29(20.7 \%)$ & $25(17.8 \%)$ \\
\hline 3 & $\begin{array}{l}\text { It gives beneficiaries the needed technical } \\
\text { skills }\end{array}$ & $20(14.3 \%)$ & $29(20.7 \%)$ & $12(8.6 \%)$ & $45(32.1 \%)$ & $34(24.3 \%)$ \\
\hline \multirow[t]{2}{*}{4} & $\begin{array}{l}\text { It helps beneficiaries } \\
\text { entrepreneurial skills }\end{array}$ & $19(13.6 \%)$ & $28(20 \%)$ & $21(15 \%)$ & $39(27.9 \%)$ & $33(23.6 \%)$ \\
\hline & $\begin{array}{l}\text { Factors Inhibiting Beneficiaries to } \\
\text { Practice skills acquired from training. }\end{array}$ & & & & & \\
\hline 5 & $\begin{array}{l}\text { Huge amount of money is needed before } \\
\text { opening vocational venture }\end{array}$ & $20(14.3 \%)$ & $31(22.1 \%)$ & $16(11.4 \%)$ & $31(22.1 \%)$ & $42(30.0 \%)$ \\
\hline 6 & $\begin{array}{l}\text { The competition in vocational ventures } \\
\text { was high }\end{array}$ & $27(19.3 \%)$ & $14(10.0 \%)$ & $61(43.6 \%)$ & $20(14.3 \%)$ & $18(12.9 \%)$ \\
\hline 7 & Limited training skills was acquired & $19(13.6 \%)$ & $15(10.7 \%)$ & $16(11.4 \%)$ & $56(40.0 \%)$ & $34(24.3 \%)$ \\
\hline 8 & $\begin{array}{l}\text { High interest rate on loan was } \\
\text { discouraging to set up a venture }\end{array}$ & $22(15.7 \%)$ & $13(9.3 \%)$ & $20(14.3 \%)$ & $52(37.1 \%)$ & $33(23.6 \%)$ \\
\hline
\end{tabular}

Source: Field Data, 2015 


\subsection{Part Three}

\subsubsection{Responses from Relevant Stakeholders}

Key stakeholders in vocational education are; Ghana Education service, Ministry of Education, teachers etc. and the development and approach to dealing with issues that confront vocational education in the Ashanti region is predicated on how these stakeholders perceive vocational education. Information was sourced from 40 stakeholders. On analysis the responses from the respondents putting together their responses on agreed and strongly agreed; disagree and strongly disagreed, it was evident that stakeholders have satisfactory perception about the training given to vocational students. This can be seen in table 4.6 below where $18(45 \%)$ of the stakeholders agreed to the perception that they are satisfied with the training that is given to vocational students; with $12(30 \%)$ agreeing strongly to the said assertion. Another strong perception that was held by the stakeholders is that vocational education graduates possesses necessary technical and problem-solving skills in their specialization areas; and also, vocational education is the key for development. However, most of the respondents were uncertain as to whether vocational education has reduced unemployment rate in the region over the years.

Table 4.6:

\begin{tabular}{|c|l|c|c|c|c|c|}
\hline \multicolumn{2}{|c|}{ STATEMENT } & $\begin{array}{c}\text { Strongly } \\
\text { Disagree } \\
(\mathbf{1})\end{array}$ & Disagree & $\begin{array}{c}\text { Neutral } \\
\text { (3) }\end{array}$ & $\begin{array}{c}\text { Agree } \\
\text { (4) }\end{array}$ & $\begin{array}{c}\text { Strongly } \\
\text { Agree } \\
\text { (5) }\end{array}$ \\
\hline $\begin{array}{l}\text { Stakeholders Perception about Vocational } \\
\text { Education in Ashanti Region }\end{array}$ & & & & 12 \\
\hline 1 & $\begin{array}{l}\text { Satisfied with the training given to vocational } \\
\text { students }\end{array}$ & $7(17.5 \%)$ & $2(5.0 \%)$ & $1(2.5 \%)$ & $18(45.0 \%)$ & $12(30.0 \%)$ \\
\hline 2 & $\begin{array}{l}\text { Vocational education has reduced } \\
\text { unemployment rate }\end{array}$ & $5(12.5 \%)$ & $7(17.5 \%)$ & $18(45 \%)$ & $4(10 \%)$ & $6(15 \%)$ \\
\hline 3 & $\begin{array}{l}\text { Vocational education graduates possess } \\
\text { necessary technical and problem-solving skills } \\
\text { in their specialization areas }\end{array}$ & $4(10 \%)$ & $7(17.5 \%)$ & $3(7.5 \%)$ & $15(37.5 \%)$ & $11(27.5 \%)$ \\
\hline 4 & $\begin{array}{l}\text { Vocational education is the key for } \\
\text { development }\end{array}$ & $7(17.5 \%)$ & $4(10 \%)$ & $3(7.5 \%)$ & $16(40 \%)$ & $10(25 \%)$ \\
\hline
\end{tabular}

\subsection{Discussion of Results}

Making a good choice of career is a major concern of students, parents and governments since the aim of education is to help the individual develop occupational and vocational competences. According to Holland (1971) as stated in Ekpenyong (2005), the key factors influencing occupational and vocational choice of include psychological, sociological, economic, situational, political and religious. From the results, it emerged that several factors influenced the beneficiaries in their choice of vocational education, however, the most predominant factor is the ease of getting employment after the vocational school. Hence, the individuals' choice is purely economical and this consistent with the theory propounded by Hollan (1971).

On the impact of vocational education on the beneficiaries' occupational life, majority of them acknowledged that the knowledge acquired from vocational education prepares them adequately, gives them the necessary technical skills and also serve as a medium through which they acquired entrepreneurial skills.

Aside the numerous benefits that have been alluded to vocational education there exist some factors that inhibited the beneficiaries from actualizing and manifesting the practical knowledge acquired in real life. Some of these factors are the huge amount of money needed to open a vocational venture, limited training skills acquired, and the high interest rate on loans hence discouraging for beneficiaries from accessing start-up capital.

In a nutshell, resolving the numerous bottlenecks that limit the full potential of vocational education in economic development is largely dependent on the perception of relevant stakeholders about vocational education. From the study, the stakeholders have a positive outlook about vocational education and currently did not see any shortcomings and challenges that confront vocational education. This is quite strange because the direct beneficiaries have highlighted the various limitations of the vocational education system and the numerous external factors that limit its potential. It is therefore, crucial for stakeholders to solicit information from beneficiaries so that they can identify key issues that confront vocational education and how to go about resolving them.

\subsection{Conclusion}

The role of vocational education in economic development cannot be overemphasized; and a developing country like Ghana needs to prioritized vocational and technical education in order to provide employment to the teaming unemployed youth in the country. Again, vocational and technical education development is the bedrock for technological advancement in very country. Therefore, Ghana's quest for technological development will be 
fruitless without deliberate investment into vocational and technical education.

Nevertheless, developing vocational education requires a complete understanding of the factors affecting vocational education development and the areas that are deficient in the vocational system. This current study that was conducted in the Ashanti Region - the most populous region in Ghana; highlighted key factors that influence people to enrol in the vocational education system, identified the impact of vocational education on the occupational life of beneficiaries and also examined the various factors that inhibit beneficiaries from actualizing practical skills acquired through vocational education. It is therefore paramount for relevant stakeholders to further investigate these issues that have been laid bared and implement necessary remedial measures to promote vocational education.

\subsection{Limitations of the study}

The study was based on the people in Kumasi Metropolis that have benefited and that in-charge of vocational education in spite of all beneficiaries in Ghana. This population was selected because of ease of accessibility due to time constraint and limited financial resources. The study would therefore not be generalized to all beneficiaries and stakeholders in Ghana but only for those in the Ashanti Region, because it does not reflect the views of all beneficiaries.

\section{REFERENCES}

Best, J. W., \& Kahn, J. W., (1993). Research in Education (7 ${ }^{\text {th }}$ ed.). New Delhi Prentice Hall. Inc.

Finn, J. (1972). Expectations and the educational environment. Review of Educational Research, 4(13), 387-410

Fraenkel, J. R., \& Wallen, N. E., (2000). How to design and evaluate research in education (4th ed.). Boston: McGraw Hill.

Gay L.R., (1992). Education Research: Competence for analysis and application. New York: Maxwell Macmillam International

Herkert, J. R. (2002). Continuing and emerging issues in engineering ethics education. The Bridge, 32(3). Washington, DC: National Academy of Engineering. Retrieved from : http://www.nae.edu/Publications/Bridge/EngineeringEthics7377/ContinuingandEmergingContinuingEmerg ingIssuesEngin.aspx [Google Scholar]

Manifred, T., \& Jennifer W., (2000). Vocational Education and training: Key to the future. Greece. Colibri Limited.

Murray, B. (2004). A Study of the Influence Vocational Education has on Students' Ultimate Academic Success

Mustapha R.B., \& Greeman, J.B., (2002). The role of vocational education in economic development of Malaysia: Educationists and employers Perspectives Journal of Industrial Teacher Education 3 9(2).

Polit, D.F., \& Hungler, B.P., (1997). Essentials of nursing research: Methods, appraisals and utilisation. $4^{\text {th }}$ edition. Philadelphia: Lippincott-Raven Publishers.

Seyfried, E., (1998). Evaluation of Quality Aspects in Vocational Training Programmes: Synthesis Report, CEDEFOP

Shantaram M. S. (2012). A Study of Significance of Vocationalization of Education and Skill Development in India with special reference to the State of Maharashtra

Sherry J.L., Tamborini R., Weber R., Bowman N.D. (2013). Facilitating Game Play: How Others Affect Performance at and Enjoyment of Video Games. Media Psychology; Motimer Street, London.

Ugwuja, O.G., (2010). Influence of family background on the academic achievement of senior secondary school students in Nsukka educational zone of Enugu State. Department of Educational Foundations, Faculty of Education. University of Nigera Nsukka. 